\title{
UGGT2 wt Allele
}

National Cancer Institute

\section{Source}

National Cancer Institute. UGGT2 wt Allele. NCI Thesaurus. Code C150052.

Human UGGT 2 wild-type allele is located in the vicinity of $13 q 32.1$ and is approximately $252 \mathrm{~kb}$ in length. This allele, which encodes UDP-glucose:glycoprotein glucosyltransferase 2 protein, is involved in protein folding quality control. 